\title{
Massive, Open, Online, and National? A Study of How National Governments and Institutions Shape the Development of MOOCs
}

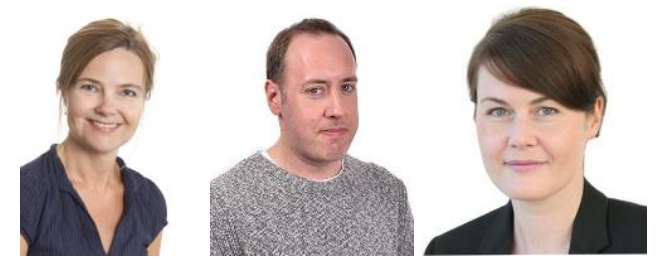

Cathrine E. Tømte, Arne Martin Fevolden, and Siri Aanstad

Nordic Institute for Studies in Innovation, Research and Education, NIFU

\begin{abstract}
We explore interpretations of MOOCs around the globe and, in particular, interpretations of MOOCs in Norway. Based on a review of previous studies relevant to these topics, we present two contrasting views on the emergence and development of MOOCs, namely the global interruption view and the national mediation view. We suggest, based on previous studies that MOOCs seem to follow national paths more than global paths. In order to grasp the diversity of understandings of MOOCs, we developed a framework that embraces various aspects of motivation, context, and structure regarding MOOCs. With these two polarised views of MOOC development (the global interruption view and the national mediation view), and the framework serving as an analytical approach, we looked at Norway and analyzed the understandings of the development of MOOCs within this particular national context. The national government seems to have been important in the development of the present MOOCs in Norway, both by organizing a particular group of experts in a dedicated commission to consider the future of MOOC in Norway, and by initiating and giving financial support to the development of MOOCs.
\end{abstract}

Keywords: MOOC, online learning, global and national pathways, motivations

\section{Introduction}

According to The New York Times, the year 2012 was "the year of the MOOC" (Pappano, 2012). In that year, several MOOC (Massive Online Online Courses) providers-such as edX, Coursera and Udacity-teamed up with prestigious universities and began to offer free online courses in a range of academic subjects. The MOOCs became such an astounding success that in less than a year after they 
were established they reached over a million students. Nevertheless, the MOOC phenomenon did not peak in 2012, but continued in subsequent years to expand along several dimensions. It expanded in terms of geography, with higher education institutions (HEIs) from many parts of the world offering MOOCs, including new MOOC providers other than those based in the U.S. (Adham \& Lundquist, 2015; Brandon, Christensen, \& Kapur, 2015; Bonk, Lee, Reeves, \& Reynolds, 2015; Jansen \& Schuwer, 2015). It expanded in terms of breadth, with providers employing widely different pedagogies and offering a variety of subjects and accreditation forms (Hayes, 2015; Porter \& Beale, 2015).

Due to the sheer magnitude of the MOOC phenomenon, many commentators agreed that MOOCs might transform higher education (Mazoue, 2013; Gaebel, Kupriyanova, Morais, \& Colucci, 2014; Schuwer et al., 2015). Nonetheless, how they might change higher education is much debated (Yuan and Powell, 2013; Veletsianos and Shepherdson, 2016; Knox, 2016), and that is the topic of this article.

It is possible to distinguish between two different groups of commentators based on their views on MOOC. The first group-which includes media such as The Economist and MOOC founders such as $\mathrm{Ng}$ (The Economist, 2014; Ng, 2013)-describe MOOCs as a global disruptive force. They believe that MOOCs will make teachers redundant by moving lectures onto the Internet and create a global market for education dominated by a few elite universities. In the following, we will refer to their view as the "global disruption view." The other group includes researchers who view MOOCs as another elearning technology that will be adopted and implemented nationally (Yuan \& Powell, 2013; Bonk et al., 2015; Jansen, Schuwer, Teixeira, \& Aydin, 2015). These researchers believe that governments and HEIs will adopt and develop MOOCs according to national needs, creating distinct national development paths. We will refer to their view as the "national mediation view."

This article aims to investigate which of the two views-global disruption vs. national mediationmost accurately describes the development path of MOOCs. The article will investigate this question partly by discussing the existing literature on these particular perspectives on MOOCs, and partly by carrying out an in-depth case study of Norway. Norway is an especially interesting country to investigate since the government has played an active role in developing MOOCs. Furthermore, Norway has a long tradition in distance education. Most higher education institutions (HEIs) are public, and education is free for everyone, which may bring new perspectives on how countries with this kind of educational system approach the idea of openness that comes with the MOOCs.

Bearing this in mind, this article aims to answer the following two questions:

- Do MOOCs follow a global or national development path(s)?

- What characterizes the Norwegian path of MOOC development?

These questions are important because the two different development paths will have important consequences for higher education governance. If MOOCs are to be considered as a global disruptive force, national education authorities will need to adjust their educational systems to international providers holding particular views and standards on privacy, content, and accreditation, to mention just a few. On the contrary, if MOOCs are seen as nationally developed and adopted, national education authorities will need to work out how to adjust their educational systems to concepts of MOOCs. The main finding in this article is that during the short history of MOOCs, from about 2012 
to the present, the "national mediation" view has gained ground and dominates the ongoing development of MOOCs in Norway.

We have organized the article as follows: Section 2 provides a review and analyses of the MOOC literature regarding developments paths and interpretations of MOOCs. Section 3 presents the sources of data covering the Norwegian case, followed by section 4, which presents findings and analysis of development of MOOCs in Norway. Section 5 discusses findings from the Norwegian case in the light of the international research body of literature of development paths, with conclusions on the research questions.

\section{Do MOOCs Follow a Global or National Development Path(s)?}

\section{Short Introduction to the Origins of MOOCs}

A few years after "the year of the MOOCs" they are still in an explorative phase, as is research reporting on such initiatives. The term "MOOC" seems to have originated as a description of a course on "Connectivism and Connective Knowledge," taught in 2008 by two professors at the University of Manitoba, Canada (Young, 2013). Nonetheless, even if professors at the University of Manitoba might have founded the first official MOOC, it would be professors at American Ivy League universities that brought MOOCs into the limelight (Baggaley, 2013; Young, 2013). Although the media began to describe edX, Coursera and Udacity as MOOCs, they were in many ways different from the MOOC at the University of Manitoba. Commentators would later argue that the difference between them ran deeper and involved different learning philosophies, and they started to refer to the MOOCs established at Manitoba as "Connectivist MOOCs" or "cMOOCs" and to edX, Coursera and Udacity as "xMOOCs" (Baggaley, 2013). There have also been several attempts to challenge this restricted division of MOOCs into cMOOCs and xMOOCs (Conole, 2013; Gaebel, 2013).

Nevertheless, online education has a history that predates the MOOCs by at least a decade. Higher education institutions around the globe have offered online courses since the mid-1990s. These HEIs had extensive experience with distance-based education and learning, which again existed long before the introduction of modern Information and Communication Technology (ICT) (Casey, 2008). One of the more notable examples of a "traditional" online learning provider is the UK Open University Milton Keynes (OU) initiative. There are also other online learning initiatives from which origins of MOOCs derive, such as OpenCourseWare (OCW) and Open Educational Resources (OER) (Official Norwegian Reports NOU, 2014). These initiatives resembled MOOCs in the sense that they provided educational resources free for everyone on the Internet.

\section{The Diversity of MOOCs}

As described, various initiatives and processes seem to have influenced the emergence of MOOCs. We may also relate MOOCs to a wider landscape of technology-enhanced learning, including concepts such as e-learning, blended/hybrid learning, and various understandings of online learning. Due to this diversity of origins and similarities to various related technology-enhanced learning activities, researchers have highlighted the difficulties of defining a MOOC (Siemens, 2012; Bates, 2014; Read \& Rodrigo, 2014; Tømte, Fevolden, \& Olsen, 2014). Even if there are several understandings and interpretations of what constitutes MOOCs, these remain poorly defined as they can be interpreted in 
various ways and adjusted to countries' existing education systems. However, Jansen and Schuwer (2015) suggest that one central approach has gained ground in Europe: "MOOCs are online courses designed for large number of participants, that can be accessed by anyone anywhere as long as they have an internet connection, are open to everyone without entry qualifications, and offer a full/complete course experience online for free" ( $p$ 11). This definition includes interpretations of the MOOC abbreviation in that "online courses designed for large number of participants' constitutes the 'M' (Massive); 'accessed by anyone anywhere as long as they have an internet connection,' the O' (Online): 'open to everyone without entry qualifications,' the 'O' for (Open); and 'complete course experience online for free', which the 'C' (Courses) stands for" (Jansen \& Schuwer, 2015, pp 11-12).

Researchers demonstrate how countries adopt and adjust MOOCs to their cultural, social, political, and economic situation, and to their technological infrastructure and organization of higher education. For example, in the Middle East, several countries have focused on offering courses or course content in the Arabic language, by translating and adjusting existing courses in English; for example, from edEx; and by developing new courses in Arabic (Adham \& Lundquist, 2015). Also in Europe, language, culture, and educational policies are influencing new MOOCs (Schuwer et al., 2015). Proponents of MOOCs also highlight access to education for all. In countries that struggle with insufficient technological infrastructure, local solutions emerge; for example, the establishment of study centres (Bonk et al., 2015). Cultural aspects may, for example, include gender issues, which again have appeared to be a key driver in various parts of the world. Whereas Adham \& Lundquist (2015) highlight the possibilities for women to access education in the Middle East through online education, Brandon et al. (2015) stress that women and rural populations are particularly disadvantaged in accessing such resources. Whenever economic perspectives are important for countries to get involved in MOOCs, scalability serves as a major driver (Adham \& Lundquist, 2015; Bonk et al., 2015; Jansen \& Schuwer, 2015).

When comparing MOOC strategies in countries in Europe and the U.S., researchers found significant differences in motivation for adopting MOOCs (Jansen et al., 2015). One significant difference by HEIs in the U.S. and Europe was perspectives on the potential of MOOCs as a sustainable method for offering courses. Moreover, in Europe MOOCs seem to have revitalized online learning within HEIs (Teixeira, Volungeviciene, \& Mazar, 2014). Schuwer et al. (2015) studied how experienced open and distance learning (ODL) leaders from several European HEIs with considerable experience with MOOCs approached and judged opportunities and threats of MOOCs in HEIs. They found that most of these include accreditation (ECTS), innovation, and availability of multiple platforms (Schuwer et al., (2015). Interestingly, these issues are sometimes interconnected or representing both sides. For example, MOOCs may enhance institutional collaboration, and the ECTS system may serve as appropriate for accreditation by ECTS of MOOCs. MOOCs may bring innovative and alternative pedagogical models into HEIs; but this may also be a difficult process due to too much regulation within the institutions. Following this, in the Nordic countries, except Sweden, MOOCs are connected to existing procedures for organizing continuing education/lifelong learning within HEIs. This way, students sign up for a MOOC offered by HEIs as either a MOOC student or as a regular student, the latter including paying an admission fee and following examination procedures, including achieving student points/regular accreditation. However, whereas conventional online courses are limited in scale, these MOOCs include a considerably larger number of students (Kahlroth, Ejsing, Herjevik, \& Karlsson, 2016). 
As briefly demonstrated here, different countries have different approaches, motivations, and interpretations of MOOCs, and this diversity may affect how MOOCs are developed and adopted within national education systems. In section 3 , we delve deeper into some of these local and national interpretations, by looking at Norway.

\section{Discussion of Global Disruption vs. National Mediation}

We distinguish between two different views on MOOCS-which we have labelled the "global disruptive" view and the "national mediation" view, and which represent two different perspectives on what MOOCs are and what kind of development path they will follow. The two views can be seen as two extremes between which many pundits would place themselves. In our article, these two views serve as two hypotheses that we will compare and contrast against developments in the Norwegian higher education sector.

The global disruptive view is supported by The Economist and MOOC entrepreneurs such as $\mathrm{Ng}$ (Ng, 2013; The Economist, 2014). Proponents of this view look at MOOCs through economic and business lenses, seeing MOOCs as an innovation that will alter the competitive dynamics within the higher education sector. They argue that MOOCs enable a higher education institution to benefit from the same economies of scale as the software and semiconductor industries, where development of processors and programmes is costly, but the production of the processors and programmes is relatively inexpensive. They also point out that MOOCs eliminate boundaries of distance, and essentially create a global market for higher education. The result of these changes, they believe, is that a few, perhaps American, elite universities will provide higher education to the world. Diverse studies on MOOCs (e.g., Jacoby, 2014; Ossiannilsson, Williams, Camilleri, \& Brown, 2015), discuss if MOOCs may affect teaching and learning due to their disruptive characteristics in terms of size, openness, and grading. Moreover, the presence of this argument was confirmed by Selwyn and colleagues when analyzing MOOCs in newspapers (Selwyn, Bulfin, \& Pangrazio, 2015).

The proponents of the global disruptive view refer to two theories from business studies and economics to justify their arguments-Clayton M. Christensen's theory of "disruptive innovations" (Bower and Christensen 1995; Christensen, 1997) and William J. Baumol's theory of "cost disease" (Baumol \& Bowen, 1966; Bowen, 2013). Christensen argued that many established companies ended up "out-performing" their markets by providing products or services that were of a higher quality than the market demanded and that these companies could easily be replaced by newcomer companies that provided somewhat inferior products or services but at a much lower cost. Baumol, on the other hand, argued that labour-intensive sectors (such as higher education) will experience a cost pressure over time, since the salaries in these sectors then to increase along with national economic growth, but cannot be offset by increases in productivity. By combining these two theories, the proponents find justification for arguing that the lagging productivity among traditional higher education institutions will lead to soaring costs of education and pave the way for disruptive alternatives, such as MOOCs, that will eventually replace most of them.

On the other hand, the national mediation view is supported by, for example, e-learning researchers and policy analysts (Yuan \& Powell, 2013; Bonk et al., 2015; Jansen et al., 2015). Proponents of this view look at MOOCs through the lenses of education and higher education governance, and see MOOCs as another e-learning technology to be adopted nationally. Whereas some of these proponents highlight the innovative potential of MOOCs in that they may enhance changes even in campus-based teaching and learning activities (Jansen \& Schuwer, 2015), others are more critical towards the 
pedagogical potential that comes with MOOCs (Bates, 2014; Margaryan et al., 2015; Knox, 2016). Another issue debated among these proponents is how development of MOOCs as collaboration between HEIs may strengthen quality in teaching and learning within a national education system (Official Norwegian Reports NOU, 2014; Adham \& Lundquist, 2015, Ossiannilsson et al., 2015; Kahlroth et al., 2016).

\section{Typology of MOOCs}

The premise of this article is that MOOC developments follow national paths, and its main ambition is to describe the Norwegian path of MOOC development. From the discussion above, we have seen that MOOCs have appeared in variety of forms. We have seen that organizations such as edX and Coursera have provided online courses to large groups of potential students, but that they offer little in the form of accreditation other than badges and diplomas. However, we have seen that HEIs such as the UK Open University have provided online courses to smaller groups of students, yet offered full accreditation of the education provided. We have also seen that the HEIs vary in their motivations for offering MOOCs, and cultural, economic, and political contexts influence the developments. These differences among MOOCs offer a potential to classify them and use these classifications to describe different national paths of MOOC development.

These two insights allow us to distinguish between different approaches to MOOCs-in terms of both motivation and content. If we start with the content, we have seen that MOOCs vary in terms of their target groups and in terms of accreditation. Some MOOCs target a broad student group regarding geography, occupation and educational level. These mass-market MOOCs usually adopt a "world language" such as English, Spanish, or French, and aim to provide a course that could potentially be enjoyed by anyone with an interest in the subject. These MOOCs involve many of the courses offered by U.S. providers edX and Coursera. Other MOOCs target narrower groups of students. These nichemarket MOOCs sometimes adopt local languages, such as Norwegian, and provide courses that might target a specific occupational group such as teachers that require extension studies. Another dimension is accreditation; some MOOCs offer no or only informal validation of course completion, and do not provide units that can be used to build a degree. These informal MOOCs can, for example, be the providers edX and Coursera, which usually offer only badges or diplomas. Other MOOCs are part of the educational offerings of a HEI and offer units that can be included within the completion of a degree. As demonstrated, in Table 2, various motivations for setting up MOOCs coexist, and countries have had diverse approaches. The motivations span from scalability, openness, and access in terms of education for all, to branding the institution, innovating pedagogics, and the like.

If we combine these two categories, we can distinguish between four different types of MOOCs: massmarket formal, mass-market informal, niche-market formal, and niche-market informal. The table below describe characteristics of each of these types. 
Table 1

A Typology of MOOCs

\begin{tabular}{|l|l|l|}
\hline Formal approach & \multicolumn{1}{|c|}{ Mass-market approach } & \multicolumn{1}{|c|}{ Niche-market approach } \\
\hline $\begin{array}{l}\text { Students in terms of geography } \\
\text { and occupational background } \\
\text { and provides formal } \\
\text { recognition through course } \\
\text { credits that can count towards } \\
\text { college degrees }\end{array}$ & $\begin{array}{l}\text { Targets a narrow group of } \\
\text { students in terms of geography } \\
\text { and occupational background } \\
\text { and provides formal } \\
\text { recognition through course } \\
\text { credits that can count towards } \\
\text { college degrees }\end{array}$ \\
\hline Informal approach & $\begin{array}{l}\text { Targets a broad group of } \\
\text { students in terms of geography } \\
\text { and occupational background } \\
\text { \& provides informal } \\
\text { recognition through badges or } \\
\text { diplomas }\end{array}$ & $\begin{array}{l}\text { Targets a narrow group of } \\
\text { students in terms of geography } \\
\text { and occupational background \& } \\
\text { provides informal recognition } \\
\text { through badges or diplomas }\end{array}$ \\
\hline
\end{tabular}

Even if there have been several efforts to categorize MOOCs in various ways, we suggest that our typology, as described and illustrated in Table 1, contributes a useful overview of the diversity of MOOCs that goes beyond the overall discussion of what xMOOCs and cMOOCs and their various motivations are (Liyanagunawardena, Adams, \& Williams, 2013; Ross, Sinclair, Knox, Bayne, \& Macleod, 2014). The table is useful both to describe the Norwegian development path and to distinguish between the national mediation and the global disruption approach. The national mediation approach can be associated with the formal, niche-market types of MOOCs, since they target narrow groups of students in terms of geography and try to provide formal recognition within one or a few countries. The global disruption approach, on the other hand, can be associated with informal, mass-market types of MOOCs, since they target a broad group of students in terms of geography and do not attempt to provide any national accreditation of the courses.

Table 2

A Typology of MOOCs and Development Paths

\begin{tabular}{|l|c|c|c|}
\hline & Mass-market approach & Niche-market approach \\
\hline Formal approach & & & \\
& & & \\
\hline Informal approach & Global Disruption & & \\
& & & \\
\hline
\end{tabular}

We will therefore apply our typology of MOOCs in order to understand how development of MOOCs follows national paths, by exploring MOOCs developed in a Norwegian context. 


\section{What Characterizes the Norwegian Path of MOOC Development?}

\section{Data and Method}

This section includes a description of the Norwegian case in order to illuminate a nation's particular development path towards MOOCs. We have analyzed the developments of MOOCs in Norway in the period 2013-2015 by three sources of data: a) the public debate on MOOCs in printed media; b) the reports of a government-appointed MOOC Commission; and c) HEIs' presentations of their MOOCs on their institutional websites. This approach is in line with how Yin (2009) suggests triangulation of data. It provides us with insights from distinct sources in order to get a consistent understanding regarding characteristics of the Norwegian path of MOOC development. The media debate gives a picture of how MOOCs are perceived by a broader public audience; the reports of the MOOC Commission provide information on the Government's approach to MOOCs and the interpretations and recommendations of experts in the field; and the presentations of MOOCs on the institutional websites allow us to identify key characteristics of the national MOOC portfolio.

To get an overview of the public debate on MOOCs, we performed an informed search within the media database ATEKST, which indexes media content from nearly 100 Norwegian printed mass media, including the major national newspapers. The search included the keyword "MOOC," covering the period January 2013-December 2014. In total, we identified 106 articles on MOOCs in the Norwegian printed mass media in this period.

In June 2013, the Norwegian Ministry of Education and Research appointed a commission to examine the opportunities and challenges associated with the development of MOOCs, and provide public authorities and educational institutions with recommendations on how to relate to the development. The MOOC Commission, which included experts from the educational sector, public agencies within the area of ICT and education, industry, and regional authorities, and specialists in the field of technology and higher education, published the results from their work in two reports, one mid-term report in December 2013, and one final report in June 2014. ${ }^{1}$ These reports included the views, arguments, and analysis of these specialists, including recommendations to the government and the HEIs. In the present article, we will mainly refer to the final report, since it includes the final recommendations and overall analyses.

From 2013-2015, there were 22 MOOCs launched within Norwegian higher education institutions. We found detailed descriptions of these MOOCs regarding their particular field of discipline, target groups of students, content, accreditation procedures and the like on the official website of their distinct educational institutions. Information from the HEI websites on their MOOCs also provided us with insights regarding institutional strategies and approaches to MOOCs. Moreover, a short presentation of all MOOCs offered by Norwegian HEIs was accessible at a national MOOC-website: www.mooc.no. We based our analysis on these two sources of presentation of the 22 MOOCs; the detailed description on the HEIs' websites and at mooc.no.

${ }^{1}$ NOU 2014:5 MOOCs for Norway. New digital learning methods in higher education 
We have organized our findings and analysis into three sections, which draw on our three sources of data in various ways. The sections include: a) the public debate; b) initiatives from the Government; and c) analysis of the 22 institutional MOOCs.

\section{The Norwegian Debate}

The international development of MOOCs in recent years has attracted significant political and public interest in Norway. This section provides an overview of interpretations of MOOCs in Norway and identifies the main motivations for adopting and developing MOOCs. It covers the views of the broader public audience as expressed in the media articles on MOOCs, as well as the views of the MOOC Commission in their final report.

Interpretations of MOOCs. There are several interpretations of MOOCs in Norway, and the public debate shows that interpretations have evolved over time. Initially, many associated MOOCs with online courses developed by world-leading universities and made openly available by major international MOOC providers, such as Coursera, Udacity, and edX (Tømte et al., 2014). However, as various MOOCs spread out around the globe, the Norwegian media and the Commission approached MOOCs mainly as online courses offered by HEIs more generally, regardless of technological platform. Besides being openly available on the Internet, the main characteristics appeared to be that the courses target a high number of students outside the university campus. Initially, the media considered MOOCs mostly as free courses that did not qualify for formal study points or credits, but over the years there has been an increasing focus on the possibilities of receiving accreditation for a MOOC against a fee. There has also been an increasing focus on scalability as a defining feature.

The mandate of the government-appointed Commission was to look at MOOCs and "similar offers," and they discuss MOOCs as part of broader range of digital technologies with the potential to change higher education practices. According to the Commission's definition, there were three distinguishing features of MOOCs: they are courses that are web-based, open and scalable with regards to the number of participants. The terms "course" and "open" are broadly defined in this report, and the MOOC concept covers different types of courses spanning from continuing and further education to credit-awarding degree programmes, and courses with varying degrees of openness in terms of fees, qualification requirements, and use of open learning resources.

Motivations for adopting MOOCs. The Commission underlines that it is still an open question how MOOCs will change Norwegian higher education. It points out that Norway differs from the U.S. and many other countries around the globe in that higher education for a large part is publicly funded and free for students, and that this-along with other national idiosyncrasies-is likely to influence Norwegian developments. The Commission is of the opinion that the digitalization of higher education in Norway has been too slow, and argues that MOOCs and other new digital technologies offer major opportunities for developing the Norwegian knowledge society. In the media debate too, MOOCs are viewed mainly in positive terms, and generally, five central motivations for adopting MOOCs in Norwegian higher education are highlighted: to strengthen quality, increase access, market the education and research of HEIs and recruit students, increase cooperation, and reduce costs.

A key argument in the media debate as well as in the report from the Commission is that MOOCs have the potential to strengthen the quality of Norwegian higher education. While in the media debate, the 
argument is typically linked to the availability of high quality courses developed by international elite universities, and the MOOC Commission places strong emphasis on how Norwegian HEIs can use MOOCs strategically to change their educational practice and ensure better and more effective learning. In this context, the Commission points out that MOOCs are increasingly applied as part of campus-based education, and thus represent opportunities for strengthening educational quality through blended learning. ${ }^{2}$ The Commission also highlighted the opportunities MOOCs represent when it comes to learning analytics, which it believes to have considerable potential as a tool for quality development in higher education.

Increasing access to education was another major motivation evident in the Norwegian debate. By allowing blended or online distance-based studies, MOOCs are seen as a valuable instrument for making education more easily available for broader sections of the population. This includes groups who face barriers for attending campus-based courses; for example, relating to disability, geographical distance, or employment. The opportunities MOOCs offer when it comes to continuing education and competence development in industry and working life receive considerable attention in this context.

A third motivation is that HEIs can use MOOCs to market their education and research both nationally and internationally, and thereby position themselves in the increasing competition for students. In the media debate, this is argued to be particularly important for the university colleges in Norway, which for large part are relatively small, regional institutions.

Furthermore there is strong interest in the role MOOCs can play in increasing cooperation within the higher education sector as well as between HEIs and industry and working life. First, MOOCs are seen as an important instrument for cooperation and division of labour between HEIs; for example, by allowing them to share educational resources and specialize in the fields where they have their respective strengths. In this context it should be mentioned that cooperation, division of labour, and concentration have been key aspects of a government-initiated process to develop a stronger and more robust higher education sector in Norway. As part of the process, several universities and university colleges are merging to become large, multi-campus institutions, and for these new types of HEIs, MOOCs and other types of web-based courses that can be attended by students across geographicallydispersed campuses are highly relevant. Second, it has already been pointed out that MOOCs are considered to offer important opportunities for continuing education, and the MOOC Commission highlights their potential for strengthening cooperation between HEIs and private and public sector enterprises aimed at competence development in industry and working life.

Scalability is perceived to be a key feature of MOOCs, and attention is paid to some extent to the opportunities this represents in terms of resource efficiency and cost reduction in higher education. While the fact that higher education in Norway is free means that there is no student demand for cheaper education, the cost saving aspects of MOOCs are considered to be relevant in light of increasing government demands for cost efficiency in the sector.

\footnotetext{
${ }^{2}$ Nevertheless, one year after the Commission's final report, this statement was questioned by the publication of findings from the biannual survey on the digital state of Norwegian higher education. These findings revealed little or no awareness on how to integrate MOOCs for teaching and learning purposes by teaching staff and students (Norwegian Agency for Digital Learning in Higher Education, 2015).
} 


\section{Government Initiatives}

By appointing the MOOC Commission, the Norwegian Government initiated a process aimed at establishing a knowledge base for policy decisions relating to MOOCs and similar technological developments within higher education. It was, as pointed out earlier, part of the mandate of the Commission to give specific recommendations on how public authorities should relate to the development of MOOCs. In its report, the Commission proposes a range of policy initiatives to speed up the digitalization of Norwegian higher education and facilitate the strategic use of MOOCs in the sector. The estimated total costs of the proposed policy measures are in the range of $€ 14 \mathrm{~m}-40 \mathrm{~m}^{3}$ annually over a five-year period, and even though the Government response has not reached this ambitious level of investment, several initiatives have been made. They include the establishment of a centre for learning analytics, and an ongoing pilot project for the development and implementation of a MOOC for continued education of primary school mathematics teachers. Bibsys, a public agency owned by the Ministry, runs a national portal-mooc.no-providing an overview of Norwegian MOOCs as well as resources for institutions interested in developing MOOCs. HEIs can, for example, get access to open-source versions of the platforms Canvas and edX developed by Bibsys. Moreover, the Commission recommended the establishment of a national portal as well as a national platform, partly to ensure HEIs the opportunity to develop MOOCs in the national languages and target niche groups; for example, in Norwegian industry and working life.

MOOCs in Norway-Analyzing the 22 existing courses. As demonstrated, the government has played an active role in the development of MOOCs in Norway. Based on the 22 MOOCs registered at the mooc.no website in October 2015 and their web-based presentation at their institution, this section aims to elaborate on what constitutes the present MOOC initiatives within Norwegian higher education institutions. We describe the MOOC courses offered by the various HEIs and possible motivations for establishing these initiatives, in terms of formal and informal approach and scalability, by adopting the typology introduced in the section titled "Typology of MOOCs."

From 2013-2015, 13 distinct HEIs in Norway offered 22 MOOCs registered at the www.mooc.no website. The HEIs comprise seven universities and six university colleges; and whereas the University of Oslo offers four MOOCs, most other HEIs offer one or two courses. In one case, we find a MOOC to be a co-production by two HEIs. Most MOOCs (18) are in the Norwegian language, with only four in English. This corresponds with most of the MOOCs' aims and scope; while the four English-speaking MOOCs aim to reach an international audience, the Norwegian-speaking MOOCs target a national audience interested in a particular subject and field of knowledge, mainly for continuing education purposes rather than mainstream education. Following this, most MOOCs seem to have a kind of twofold scope in that one pathway content is open to everyone; with another pathway following routines related to formal education, such as admission, assessment, and accreditation procedures. This procedure is also followed by certain other Nordic countries that have a similar organization of HEIs (Kahlroth et al., 2016). Moreover, most MOOCs developed by Norwegian HEIs serve as supplementary courses, in that they mainly support existing courses by reaching out to a wider audience than campus-based classes. Only seven MOOCs replace existing courses. Furthermore, most MOOCs are developed and initiated by the HEIs; only four out of the 22 are initiated by governmental bodies. The MOOCs cover various disciplines, spanning from Science, Mathematics, and Journalism

3 130-380 million Norwegian kroner (NOK), conversion rate 1 EUR $=9.4$ NOK. 
to Music. However, several of the MOOCs are concerned with digital competence for the teaching profession. These MOOCs may have been developed due to teaching staff at HEIs who are interested in developing MOOCs as part of their own digital competence as teachers, and partly due to expectations from the government towards scaling up digital competence for teaching staff. We have organized all 22 in Table 4, based on the outline in Table 2.

Table 4

A Typology of MOOCs in Norway

\begin{tabular}{|c|c|c|}
\hline $\begin{array}{l}\text { MOOCs } \\
\text { in } \\
\text { Norway }\end{array}$ & Mass-market approach & Niche-market approach \\
\hline $\begin{array}{l}\text { Formal } \\
\text { approach }\end{array}$ & & $\begin{array}{l}\text { UiO: FlexPhil } \\
\text { UiO: Chemistry online } 1 \\
\text { UiO: Chemistry online } 2 \\
\text { NTNU: Smart learning } \\
\text { UiS: Medicine calculation } \\
\text { UiS: Digital composer studies } \\
\text { NMBU: Basic statistics } \\
\text { Hiø: ICTMOOC - introduction to ICT } \\
\text { NTNU: ICT in learning } \\
\text { HiV: Learning design } \\
\text { HiV: GenealogyMOOC-course in } \\
\text { genealogical research } \\
\text { UiB: Multimedia journalism } \\
\text { HiL: School-based MOOC in Assessment for } \\
\text { learning } \\
\text { UiT/NTNU: MathematicsMOOC }\end{array}$ \\
\hline $\begin{array}{l}\text { Informal } \\
\text { approach }\end{array}$ & $\begin{array}{l}\text { UiO: What works } \\
\text { UiB: Natural Resources Management } \\
\text { UiA: Success-unleash yourself } \\
\text { NTNU: Diversification in Time and } \\
\text { Space }\end{array}$ & $\begin{array}{l}\text { UiO: FlexPhil } \\
\text { UiO: Chemistry online } 1 \\
\text { UiO: Chemistry online } 2 \\
\text { NTNU: Smart learning } \\
\text { UiS: Medicine calculation } \\
\text { UiS: Digital composer studies } \\
\text { NMBU: Basic statistics } \\
\text { HiØ: ICTMOOC-introduction to ICT } \\
\text { NTNU: ICT in learning } \\
\text { HiV: Learning design } \\
\text { HiV: GenealogyMOOC-course in } \\
\text { genealogical research } \\
\text { UiB: Multimedia journalism } \\
\text { HiL: School-based MOOC in Assessment for } \\
\text { learning } \\
\text { UiT/NTNU: MathematicsMOOC } \\
\text { Westerdals: Animation and method } \\
\text { Westerdals: Games and gamification }\end{array}$ \\
\hline
\end{tabular}

As demonstrated in Table 4, none of the Norwegian MOOCs can be associated with a formal and mass-market approach. On the contrary, most of these MOOCs serve diverse niche-markets in terms of disciplines, languages, target groups, and scope. For example, most of these MOOCs target a national audience with a clear aim to serve continuing education purposes, in a scalable and cost efficiently way. The four MOOCs in English language differ from these as they target an international audience and aim to brand institutional expertise in these particular topics (Hollands \& Tirthali, 2014; Andresen, 2016). 


\section{Overall Discussion and Conclusions}

In this article, our aim was to explore whether MOOCs follow a global or national development pathand, in particular, what characterizes the Norwegian path of MOOC development. Based on a review of previous studies relevant to these topics, we presented two contrasting views on the emergence and development of MOOCs, namely the global disruption view and the national mediation view. We suggested, based on previous studies that MOOCs seem to follow national paths more than global paths, and that there has been a shift in scope over the years. In the early years of MOOCs, from about 2012, the global disruption view dominated in the media and elsewhere, whereas in the last couple of years the media and various studies highlight and confirm the multiplicity of MOOCs, including new initiatives beyond the U.S.-based MOOC platform providers emerging around the globe. In order to grasp this diversity of understandings of, and approaches to, MOOCs, we developed a framework that embraced various aspects of motivation, context, and structure regarding MOOCs. With these two polarized views of MOOC development (the global disruption view and the national mediation view), and the framework serving as an analytical approach, we looked at Norway and analyzed the understandings of the development of MOOCs within this particular national context. This also serves as a first attempt to validate the framework in one distinct national context. As previously demonstrated, countries around the globe hold various motivations and interpretations on MOOCs, mainly due to their educational systems, cultures, economic and technological systems, and infrastructures. This diversity also influences the uptake and shaping of MOOCs. We hope that our framework may be useful in order to systematically approach, organize, and understand MOOC initiatives in other countries. In the present paper we have demonstrated the potential of it in the case of Norway. Future studies might include other countries with other education systems and governance in order to explore, validate, and refine our framework.

\section{References}

Adham, R., S. \& Lundqvist, K., O. (2015). MOOCS as a method of distance education in the Arab world - A review paper. European Journal of Open, Distance and E-Learning, 14(1), 1027-5207

Andresen, A. H. (2016). The Norwegian MOOC: Objectives and development of massive open online courses in Norway. (Master's thesis) University of Oslo, Oslo. Retrieved from https://www.duo.uio.no/handle/10852/51945

Baggaley, J. (2013). MOOC rampant. Distance Education, 34(3), 368-378. doi:10.1080/01587919.2013.835768

Bates, T. (2014). Teaching in a digital age. Tony Bates Associates Ltd. Retrieved from http://opentextbc.ca/teachinginadigitalage/

Baumol, W. J., \& Bowen, W. G. (1966). Performing arts, the economic dilemma: A study of problems common to theater, opera, music, and dance. New York: Twentieth Century Fund. 
Bonk, C. J., Lee, M. M., Reeves, T. C., \& Reynolds, T. H. (Eds.). (2015). MOOCs and open education around the world. New York: Routledge.

Bowen, W. G. (2013). Higher education in the digital Age. Princeton: Princeton University Press.

Bower, J. L., \& Christensen, C. M. (1995). Disruptive technologies: Catching the wave. Harvard Business Review, 73(1), 43-53.

Brandon, A., Christensen G., \& Kapur, D. (2015). Higher education and MOOCs in India and the Global South. Change: The Magazine of Higher Learning, 47(3), 42-49.

Casey, D. M. (2008). A journey to legitimacy: The historical development of distance education through technology. TechTrends: Linking Research and Practice to Improve Learning, 52(2), $45-51$.

Christensen, C. M. (1997). The innovator's dilemma: When new technologies cause great firms to fail. Boston, Massachusetts: Harvard Business School Press.

Conole, G. (2013). MOOCs as disruptive technologies: Strategies for enhancing the learner experience and quality of MOOCs. (Preprint). Retrieved from http://eprints.rclis.org/19388/

Gaebel, M. (2013). MOOCs massive open online courses. EUA Occasional Paper. Brussels: European University Association. Retrieved from http://www.eua.be/Libraries/Publication/EUA Occasional papers MOOCs.sflb.ashx

Gaebel, M., Kupriyanova, V., Morais, R., \& Colucci, E. (2014). E-learning in European higher education institutions: Results of a mapping survey conducted in October-December 2013. Brussels: European University Association.

Hollands, F., \& Tirthali, D. (2014). Why do institutions offer MOOCs? Online Learning (formerly Journal of Asynchronous Learning Networks), 18(3), 1-19.

Hayes, S. (2015). MOOCs and Quality: A Review of the Recent Literature. QAA MOOCs Network. Retrieved from http://www.qaa.ac.uk/en/Publications/Documents/MOOCs-and-QualityLiterature-Review-15.pdf

Jacoby, J. (2014). The disruptive potential of the massive open online course: A literature review. Journal of Open, Flexible and Distance Learning, 15(1) 133-160.

Jansen, D., \& Schuwer, R. (2015). Institutional MOOC strategies in Europe. Status report based on a mapping survey conducted in October-December 2014. EADTU. Retrieved from http://www.eadtu.eu/documents/Publications/OEenM/Institutional MOOC strategies in Europe.pdf

Jansen, D., Schuwer, R., Teixeira, A., \& Aydin, C., H. (2015) Comparing MOOC adoption strategies in Europe: Results from the HOME project survey. The International Review of Research in Open and Distributed Learning, 16 (6). Retrieved from http://www.irrodl.org/index.php/irrodl/article/view/2154 
Kahlroth, M., Ejsing, C., Herjevik, M., \& Karlsson, N. (2016). Öppna nätbaserade kurser (MOOCs) $i$ svensk högskola: Redovisning av ett regeringsuppdrag [Open Online Courses (MOOCs) in university colleges in Sweden: Presentation of a government assignment]. Universitetskanlsersâmbetet. Rapport 2016:1.

Knox, J. (2016). Posthumanism and the MOOC: opening the subject of digital education. Studies in Philosophy and Education, 35(3), 305-320

Liyanagunawardena, T. R., Adams, A. A., \& Williams, S., A. (2013). MOOCs: A systematic study of the published literature 2008-2012. The International Review of Research in Open and Distributed Learning, 14(3), 202-227.

Margaryan, A., Bianco, M., \& Littlejohn, A. (2015). Instructional quality of Massive Open Online Courses (MOOCs). Computers \& Education, 8o, 77-83.

Mazoue, J., G. (2013). The MOOC Model: Challenging Traditional Education. EDUCAUSE Review. Retrieved from http://www.educause.edu/ero/article/mooc-model-challenging-traditionaleducation

$\mathrm{Ng}$, A. (2013). Learning From MOOCs. Inside Higher Ed, 24(1). Retrieved from https://www.insidehighered.com/views/2013/01/24/essay-what-professors-can-learn-moocs

Official Norwegian Reports NOU. (2014). MOOCs for Norway-New digital learning methods in higher education. The Ministry of Education and Research. Retrieved from https://www.regjeringen.no/contentassets/ff86edace9874505a3381b5daf6848e6/en$\mathrm{gb} / \mathrm{pdfs} /$ nou201420140005000en_pdfs.pdf

Ossiannilsson, E., Williams, K., Camilleri, A., \& Brown, M. (2015). Quality models in online and open education around the globe. State of the art and recommendations. Oslo: International Council for Open and Distance Education 2015.

Porter, D., \& Beale, R. (2015). A Policy Brief on MOOCs. The Commonwealth of Learning. Retrieved from http://oasis.col.org/bitstream/handle/11599/825/Policy Brief on MOOCs May $25 \mathrm{HQ}$ print.pdf? sequence $=1$ \&isAllowed $=\mathrm{y}$

Read, T., \& Rodrigo, C. (2014). Toward a quality model for UNED MOOCs. eLearning Papers. Retrieved from http://www.openeducationeuropa.eu/en/elearning papers

Ross, J., Sinclair, C., Knox, J., Bayne, S., \& Macleod, H. (2014). Teacher experiences and academic identity: The missing components of MOOC pedagogy. MERLOT Journal of Online Learning and Teaching, 10(1), 57-69.

Schuwer, R., Gil-Jaurena, I., Aydin, C. H., Costello, E., Dalsgaard, C., Brown, M., ... \& Teixeira, A. (2015). Opportunities and Threats of the MOOC Movement for Higher Education: The European Perspective. International Review in Open and Distributed Learning, 16(6), 2038. 
Selwyn, N., Bulfin, S., \& Pangrazio, L. (2015). Massive open online change? Exploring the discursive construction of the 'MOOC' in newspapers. Higher Education Quarterly, 69(2), 175-192.

Siemens, G. (2012). MOOCs are really a platform. eLearnspace. Retrieved from http://www.elearnspace.org/blog/2012/07/25/moocs-are-really-a-platform/

Teixeira, A., Volungeviciene, A., \& Mazar, I. (2014). The mainstreaming of open, online and flexible learning: How will MOOCs continue to be unique from an institutional perspective. In D. Jansen \& A. Teixeira (Eds.), Position papers for European cooperation of MOOCs. EADTU. Retrieved from http://home.eadtu.eu/news/95-position-papers-for-european-cooperationon-moocs

Tømte, C., Fevolden, A., M., \& Olsen, D., S. (2014). To MOOC or not to MOOC? The Norwegian Case in eLearning as a Socio Cultural System - A Multidimensional Analysis. IGI Global

Pappano, L. (2012, November 4th). The year of the MOOC, The New York Times. Retrieved from http://www.nytimes.com

Yuan, L., \& Powell, S. (2013) MOOCs and open education: Implications for higher education: A white paper (JISC Cetis; Centre for educational technology \& interoperability standards). Retrieved from http://publications.cetis.ac.uk/wp-content/uploads/2013/03/MOOCs-and-OpenEducation.pdf

Young, J. R. (2013), Beyond the MOOC hype: A guide to higher education's high-tech disruption. The Chronicle of Higher Education. Washington.

Yin, R. K. (2009). Case study research: design and methods. Thousand Oaks, CA: SAGE Publications.

Veletsianos, G., \& Shepherdson, P. (2016). A systematic analysis and synthesis of the empirical MOOC literature published in 2013-2015. International Review of Research in Open and Distributed Learning, 17(2).

\section{Athabasca}

University

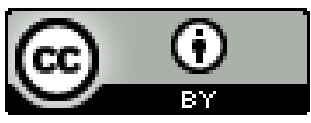

